\title{
Creating Partnerships for Complex Learning: The Dynamics of an Interest-Based Apprenticeship in the Art of Sculpture
}

JEAN C. MCPHAIL

University of Canterbury

Christchurch, New Zealand

JOANNE M. PIERSON

University of Michigan

Ann Arbor, Michigan, USA

JULIE GOODMAN

University of Michigan

Ann Arbor, Michigan, USA

JANE BUNGE NOFFKE

Artist/Sculptor

Ann Arbor, Michigan, USA

\begin{abstract}
This is a story of 10 middle school students identified with learning disabilities who, along with their teacher, worked together in a human-form sculpture apprenticeship. Their participation was based on their expressed interests in art. Within the apprenticeship, designed and conducted as a studio art class and led by a professional sculptor, the apprentices confronted and solved a series of artistic problems as they each created two sculptures. Our study focuses on the apprentices and their mentor as they struggled to articulate and understand the multiple ways they made meaning of their apprenticeships, and how the experiences came to affect their lives. We wanted to know how the act of artistic engagement could, for example, lead an apprentice to "see different things... see people differently...f feel stronger inside." To this end, we have used the various texts of the participants to examine the meaning of genuine interest as revealed in their commitment to art. We look at the apprenticeship as creating a context for dialogue between coparticipants-a dialogue that transcends the commonplace. We examine the place of art-centered experiences in learning and we explore learning within a context of enculturation. The shared apprenticeship experiences created a learning

(c) 2004 by The Ontario Institute for Studies in Education of the University of Toronto.

Curriculum Inquiry 34:4 (2004)

Published by Blackwell Publishing, 350 Main Street, Malden, MA 02148, USA, and 9600 Garsington Road, Oxford OX4 2DQ, UK.
\end{abstract}


narrative about art, about themselves, and each other-learning that included both the communal and individual meaning-making voices. In the process of constructing meaning from their unique subjectivities, the student apprentices transformed their learning narratives from "disabled" to "abled," becoming learners who were interested, engaged, and competent in their eyes and in the eyes of others. Our work suggests that interest-based learning that is guided by a talented, committed mentor can offer learning opportunities for middle schools students with specific learning disabilities not offered in conventional school contexts.

Insofar as education is concerned with developing the individual's ability to secure diverse forms of meaning through experience, then the ability to encode and decode the content embodied in different forms of representation is also of crucial importance. Such ability can be regarded as a form of literacy. The concept of literacy, as I have used it, is not limited to things said: it extends to things represented. I choose to use the term generically as the power to encode or decode meaning through any of the forms that humans use to represent what they have come to know.

(Eisner, 1982, p. xii)

Regardless of the particular case of the genetic domain involved the general point is that the introduction of a new mediational means creates a kind of imbalance that sets off changes in other elements such as the agent and change in mediated action in general. Indeed, in some cases an entirely new form of mediated action appears.

(Wertsch, 1998, p. 43)

\section{ONE STORY IN ANOTHER}

Listening again and again to the words of the apprentice sculptors and their mentor, a professional sculptor, we heard echoes of each other's interests in art and each other's experiences in learning sculpture. After eight weeks of studying together in a human-form sculpture apprenticeship, the language of these apprentices and their mentor wove a complex narrative tapestry of art, learning, and themselves. Our combined half a century of teaching and learning with apprentices like these, students who have difficulties acquiring and using conventional school literacies, and their teachers, did not prepare us for a learning story like this.

\section{Framing the Story}

In September, four university researchers (one professor, two doctoral students, and one master's student) and five sixth-grade teachers, their 31 students, and the lower-school director began collaborating on a year-long, 
interest-based, curriculum apprenticeship project. We conceptually framed this project by drawing on new theories of mind in philosophy, psychology, sociolinguistics, and cognitive studies. Scholars working in this area would suggest that "mind" is not the unitary, rational, and disembodied "entity" of traditional philosophy, but is a "subjectivized" person. These subjectivized persons become nonunitary, not purely rational, and embodied through multiple positionings in discursive practices (Bruner, 1990, 1996; Davies \& Harre, 1990; Henriques et al., 1984; Lakoff \& Johnson, 1999; Smith, 1995).

While these new views of mind have shaped our overall conceptualization of the project, we used the work of educational and psychological researchers whose pedagogical and curricular perspectives are consonant with these theories of mind to design the curriculum. In particular, the shape of the curriculum was guided by four lines of educational inquiry. To begin, we were motivated to draw on Dewey's pedagogical vision and the socioconstructivist theory of teaching and learning to design a rich and meaningful instructional context organized around a dialogical, inquirybased curriculum so as to enhance students' intellectual and social development (Dewey, 1913, 1916; Forman, Minick, \& Stone, 1993; Vygtosky, 1987, 1993; Wells, 1995). Second, we were compelled to use the work of educational and psychological researchers who have identified the positive role of students' subject-matter interests in learning (Dewey, 1913; Gottfried, 1985; Hidi, 1990; McPhail, Pierson, Goodman, \& Ayappa, 2000; Schiefele, 1991; Tobias, 1994). This work has provided evidence that when students' interact with their subject-matter interests in learning they experience a positive increase in affect and activation, and develop a mastery orientation to learning, a deep processing of subject matter, and an increase in persistence, meta-cognition, and identity formation. These positive effects of "passionate learning" have also been documented in studies of students with specific learning disabilities and dyslexia (Fink, 1995, 1998; Reiff, Gerber, \& Ginsberg, 1997). Third, we draw on the new views of intelligence that set the stage for different curricular goals and instructional designs. Gardner's (1983, 1993) theory of multiple intelligences, which privileges different kinds of symbolic thinking, and Sternberg's (1994) theory of intelligence, in which intellectual functioning is spawned in the capitalization of individual strengths and compensation for weakness, have nurtured our thinking on welcoming differences in thinking into the classroom. Working within these frames of intelligence, a small number of researchers have also identified specific strengths and aptitudes for students with specific learning disabilities and dyslexia (Hearne \& Stone, 1995; West, 1991). Last, the work on the valuable role of apprenticeship learning in acquiring performance skills and in developing identity formation through social co-participation with an expert has expanded our thinking about rich and meaningful contexts of instruction (Gee, 1996; Lave \& Wenger, 1991; Rogoff, 1990). 


\section{The Larger Project}

This year-long curriculum project involving a collaboration of researchers and teachers was conducted in an independent school for students with specific learning disabilities, dyslexia, and attention deficit disorder located in an affluent suburb of a large metropolitan area in the midwestern United States. The goal of this project was to design apprenticeships around sixth-grade students' subject-matter interests in learning. During the first half of the year, the university researchers, the teachers, and the director met in biweekly meetings during school, and three workshop dinner meetings after school, to discuss the project and design the apprenticeships. In addition, during this phase of the project, the teachers and the director engaged in all of the same "interest discovery" activities that the students would participate in antecedent to the apprenticeships. The teachers also agreed to participate as co-learners with their students in an apprenticeship that most closely reflected their interests in learning.

In the second half of the school year, the sixth-grade students initially engaged in group brainstorming sessions and individual discovery interviews designed to elicit their "genuine interests" (Dewey, 1913) in learning. From the students' expressed interests in these activities, the university researchers used semantic and conceptual mapping techniques to collapse the students' subject-matter interests into eight possible interest-based inquiry setting (IBIS) apprenticeships. Students were then asked to rank order these eight possible (IBIS) apprenticeships. Based on ranking scores and available resources, the four following apprenticeships were created: Ah, the Feel of It, the Taste of It, the Look of It; The Show Must Go On; Amazing Stunts; and Vrooooooooooooooom. These apprenticeships were designed to reflect the students' expressed interests, respectively, in doing art, in performing on the stage, in engaging in movement studies, and in learning about engines. The four teachers were then asked to choose their apprenticeship of interest.

All the apprenticeships were led by mentors employed for this project who were professionals in the respective apprenticeship areas. Initially, we met with the mentors as a group to describe the overall project, and to pair each mentor with a researcher from the university. The teacherresearch team provided them with the IBIS Literacy Framework. This framework represented the theoretical and pedagogical principles undergirding this project, and was to be used as a guide in the development of the instructional activities in their apprenticeships. However, we underscored that we regarded the mentors as the experts in their apprenticeships and, therefore, we wanted them to design their instruction in ways that were authentic to their domain. Thus, we requested that they use language and activities that supported the acquisition of the 
critical understandings and performance aspects within their areas of expertise.

All the apprenticeships met for eight weeks every Thursday and Friday afternoon during regular school hours for two hours each day during April and May. All IBIS apprenticeships were videotaped and some students ${ }^{1}$ were audiorecorded using wireless microphones. Near the end of each apprenticeship session, students, teachers, and mentors completed a onepage experience sampling methodology (ESM) (Csikszentmihalyi \& Larson, 1984) questionnaire designed to tap into their in-situ responses to the work in the apprenticeships. In addition to the ESM data, each apprentice kept a personal journal for notes, pictures, and diagrams. The researchers from the university were engaged as observers during the apprenticeship, recording each student's level, quality, and kind of engagement. The apprenticeship work terminated with an IBIS afternoon festival in which each group presented their apprenticeship projects to their parents as well as other teachers and students in the school. This IBIS Festival was videotaped. Additionally, we did retrospective interviews at the end of this project with all the apprentices, the mentors, and the lower-school director.

\section{The Art of Sculpture Apprenticeship}

In this article, we will focus on the experiences of the apprentices and their mentor in Ah, the Feel of It, the Taste of It, the Look of It apprenticeship. The focus of this apprenticeship was the study of human-form sculpture in clay. Seven girls, three boys, and one teacher were the sculptor apprentices who worked with their mentor, Jane, a professional sculptor. Of the 11 sculptor apprentices, Dennis, ${ }^{2}$ Lesley, Kim, Ellice, Paul, Claire, and Ms. Lawton were the seven persons who chose art as their first choice before, during, and after their sculpture apprenticeship. The remaining apprentices were Louise, Brittany, and Samantha, who chose this apprenticeship as their second choice, and Ted, who chose it as his third.

Jane, a sculptor with an international reputation and a quiet, kind intensity, was an experienced adult sculpture teacher, but this was the first time she had ever taught children the art of sculpture. In the spirit of apprenticeship learning, we had asked her to teach the art of sculpture as she would to anyone who was seriously interested in learning it. As a consequence, Jane designed her apprenticeship to contain the same elements as her adult studio classes. Thus, she chose to engage the students in the hands-on creation of two sculptures, a bust and a full human figure, and to provide instruction in the math, imagination, and spatial logic critical in sculpture. She also wanted them to experience the ways artists think and see the world. To maximize this kind of complex learning, Jane requested, 
and we agreed, to employ at least one additional professional artist to assist her in each sculpture class.

\section{CREATING THE NARRATIVE TAPESTRY}

In experiencing our lack of understanding of the complex learning relative to sculpture and self that emerged for the apprentices over time, we use an explanatory narrative research frame (Polkinghorne, 1988) to create a "narrative tapestry." A "narrative tapestry" was chosen as the metaphorical genre to tell a story because we wanted to create a representational form about the learning within the sculpture apprenticeship and its consequences that was reflective of the material work that engaged the apprentices. We chose a story form within the tapestry image because it is within narrative that the intimacy of experiences is safeguarded (Clandinin \& Connelly, 1994) and the unconventional educational life world can be captured best (Bruner, 1990). Also, as our narrative tapestry includes both the multiple ways individuals present the meanings in their lives in different kinds of texts (verbal and nonverbal) and the effects of these "narrative-performances" (Smith, 1995) on other people in their lives, we position ourselves as researchers and teachers actively engaged in the interpretative work of the narrative tapestry as it evolves and as we reflect on its meanings at the completion of the project.

In creating our narrative tapestry, we draw on different kinds of "texts" that arose sequentially over time that illuminate for us how the students saw sculpture and themselves, selecting interview material before they engaged in the apprenticeship, while they worked within the sculpture apprenticeship, and after they completed their work. To create a narrative tapestry inclusive of the experiences of the apprentices, their mentor, the lower-school director, and the authors, we weave together the descriptions and interpretations of these multiple texts with a particular focus on the learning of sculpture and its effects on the apprentices.

The first descriptive/interpretive text, Speaking the Language of Art: Voices from the Discovery Interviews, focuses on the apprentices' responses to select questions in the pre-IBIS individual interviews before the apprenticeship commenced. The second text, Speaking the Language of Art: Inside the Sculpture Studio-I, highlights three of Jane's teaching narratives and the apprentices' in-situ responses derived from videotapes, videotape transcripts, and audio transcripts. Speaking the Language of Art: Inside the Sculpture Studio-II presents the sculpture apprentices' responses to an individual mini-interview conducted by the mentor within the makeshift sculpture studio. The next text, Speaking the Language of Art: A Retrospective Look, draws on the post-IBIS interviews of all members of the sculpture apprenticeship and the lower-school director. We close with our own text, an epilogue that addresses our new ways of thinking about generative 
learning contexts for students who have difficulties acquiring and using conventional school literacies.

\section{Speaking the Language of Art: Voices from the Discovery Interviews}

In late February after the group brainstorming activities and the individual rankings of the eight possible IBIS apprenticeships, each student was individually interviewed by a member of the university research team. The purpose of these interviews was to come to understand the reasoning involved in students' specific subject-matter choices. All the apprentices' interviews were audio taped. For the purposes of this article, we focus on the sculptor apprentices' responses to questions pertaining to their interest in art, in general, and specifically to their selection of Ah, the Feel of It, the Taste of It, the Look of It apprenticeship.

Dennis, Lesley, Kim, Ellice, Paul, Claire, and Ms. Lawton having all chosen this apprenticeship as their primary subject-area interest spoke about their enduring emotional attachment to art in these early interviews. Dennis remembers loving to make things with his hands since before kindergarten. Lesley claimed a long-time interest in art and making things and thought she might become an artist someday because she found learning about art interesting. Another self-proclaimed budding artist, Kim, said drawing had been her favorite thing for seven years. Ellice suggested that her two-year interest in art was fueled by her artistic capabilities that were recognized by family members. However, she had selected this apprenticeship because of the reference to the art of cooking in the description and her desire to learn how to cook. Over his work in art over the last two years, Paul was particularly attracted to art because he could succeed at it, not ever "messing up" in art because he was able to fix his mistakes. Claire said she had been interested in art since she began school and liked it because she could "draw good." In her teacher workshop interview in October, Ms. Lawton, an energetic, focused, novice teacher, talked about the way hands-on activities helped her remember.

The remaining members of the sculpture apprenticeship were Louise, Ted, Brittany, and Samantha, who all chose the study of art as their second or third choice. Louise chose the math/spelling apprenticeship as her first subject-area interest and art as her second choice in spite of liking art since kindergarten. Ted doesn't talk of the length of his interest in art in this early interview, but he does tell us that his mother is an artist. He chose the vocational apprenticeship, an apprenticeship cancelled because of resources, as his first choice, and art as his third choice of study. Both he and Louise, however, spoke of the positive feelings art engendered in them because they felt accomplished in that domain. Brittany and Samantha, who both selected art as their second choice initially, were friends who both dreamed of becoming teachers. Brittany and Samantha were brought to 
the study of sculpture because their first apprenticeship, vocational exploration, had been cancelled. However, they, like Ellice, had been drawn to the art apprenticeship because of the specific reference to the art of cooking in the description. Brittany said she had liked cooking for a couple of years and Samantha remembers having an interest in cooking for six or seven years.

We turn to the work on interest of Dewey (1913) and contemporary researchers (Hidi, 1990; McPhail et al., 2000; Rathunde, 1993; Renninger, 1987; Schiefele, 1991) who highlight several features that are present in the early interviews of the sculptor apprentices. Specifically, interest work appears to confirm that "genuine interest" (see Dewey, 1913) has a relatively stable and long-lasting personal quality to it that is content specific and that contains emotional, value, and knowledge components. Except for Ellice, Brittany, and Samantha, whose interests lie in the art of cooking, all the other apprentices who talked about the length of their interest in art described being interested in art for a relatively long time. Dennis, Kim, Claire, and Louise spoke of liking art since the beginning of their school life. Lesley, while not specifying time, did suggest she had been interested in art for a "long time." Ellice and Paul spoke about a two-year interest in art. All these apprentices spoke about art with positive feelings, often tied to their enjoyment of the "hands-on" nature of doing art coupled with their perceived, personal artistic capabilities. In their extended interviews, most of the apprentices interested in art, including Ellice, make reference to the ways significant people in their lives appreciate their artistic creations. In describing one of the hallmarks of interest, Dewey (1913) talks about an "organic union" of person, materials, and the consequences of a person's actions. It would appear from the apprentices' descriptions of their interests in art that they have positive, personal identifications with the "doing" of art and the products that result from this endeavor. As a consequence, it would appear that Dennis, Claire, Lesley, Paul, Kim, and Ted have a genuine interest in art. From less information of significance at this point, Ms. Lawton also seems to be favorably disposed toward art because of its hands-on quality.

\section{Speaking the Language of Art: Inside the Sculpture Studio-I (Video Excerpts and Transcripts)}

The human-form sculpture apprenticeship was set up in the commons "lunchroom." Apprentices used the round, colorful tables that were set in a semi-circle as their workspaces. Apprentices chose their own workspaces; one apprentice preferred working alone, others always worked with the same partners. The apprentices were free to move around the room to observe and talk with each other. At the front of the semicircle, there was an easel with newsprint on it that Jane used for visual demonstrations. Next 
to this easel was Jane's demonstration bust. Jane typically worked using both two-dimensional and three-dimensional examples in her instruction. Each apprentice was given a couple of sculpting tools as their own; bags of gray clay were available for use at their discretion. Two different sculpting experiences occurred. Apprentices created their busts through observations of Jane's demonstrations as well as by observing each other's physical features. For the full-figure sculpting a live model was present.

The daily procedure began with apprentices going to the art room in the high school area to retrieve their sculptures. Before all apprentices could begin working, Jane requested that a few apprentices fill buckets with the water necessary for keeping their hands and tools clean as they worked. On most days, before working, Jane called the apprentices to the couches and chairs in one corner of the makeshift studio to have brief discussions with them about their sculpting and/or other school activities.

More than any of the other three apprenticeships, the lively intensity that surrounded the work in sculpture attracted other students, teachers, administrators, and visitors in the school. Commonly, the school administrators brought the parents of current students and prospective students into the sculpture studio. Jane remembers hearing several parents express delight and surprise to find sixth-grade students engaged in studio art experiences led by a practicing sculptor.

Like most of the sculptor apprentices, Jane had an enduring interest in art. At five years of age, she remembered wanting to be an artist, but had kept it a secret because she was afraid she wasn't one of the artistic geniuses always born with talent. Yet, as a child she always drew pictures privately in her bedroom. She still remembers fondly a second-grade teacher who let her work at her own pace on a drawing. After receiving a scholarship to study print design in college, she then switched from two-dimensional artwork to three-dimensional sculpture at the age of 27.

\section{April 30, 1998: Video and Video Transcript}

April 30 marks the sixth session in which the apprentices had been sculpting their busts. The session begins with Jane asking the apprentices to gather at the couches and chairs with their journals. After everyone is seated and comfortable, Jane introduces Kate, a new assistant, who has joined the group, and asks everyone to introduce themselves. Following the brief introductions, Jane talks about herself and sculpture.

Jane: $\quad$ This is really a nice group of students. . . I just want to let you guys know that what I usually do is [unfolds a big sheet of paper]. I have a really hard time remembering names. So I write your table down and I put your name on it. . . Y You know I have dyslexia, but I didn't have art when I was growing up in school. And I think that if I had I would have really enjoyed my schooling better. You know? 


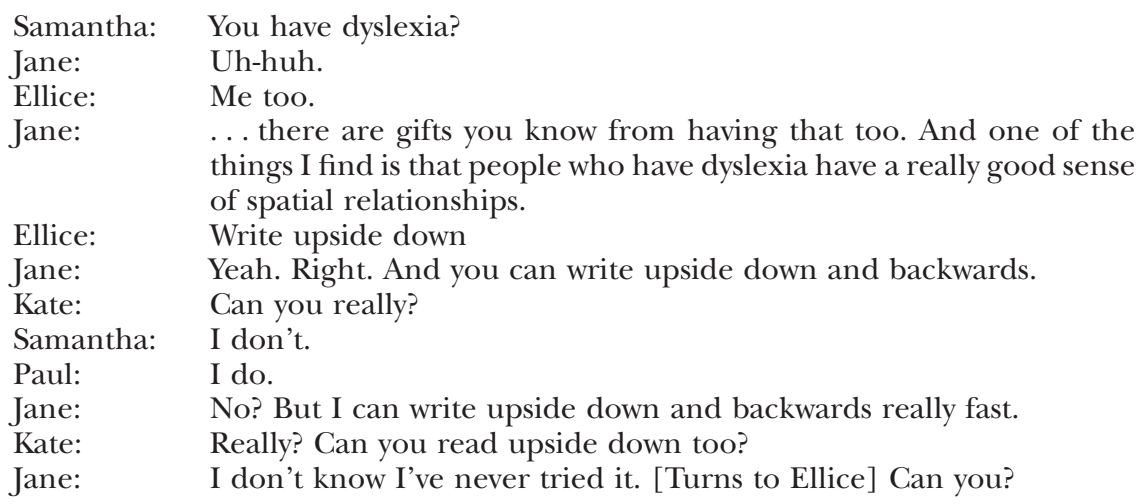

[Samantha talks about learning to write with her left hand when she broke her right.]

Jane: $\quad$. . You'll find that when you sculpt in the beginning, if you're righthanded you'll sculpt more with your right hand. After a while, like after a hour or an half hour I bet you guys will be both hands on there and you will be doing it because your brain is meshing. You're using the whole thing. It's just fascinating.

Ellice: $\quad$ My dad writes with his left hand. He writes upside down. When he was a kid, he didn't even know he was doing it.

Ms. Lawton: Brain wiring. You're using both sides of your brain.

Paul: $\quad$ My dad uses his hands and one is going this way and one is going this way. [Jane is twirling her fingers in opposite directions.]

Jane: $\quad$ My dad's dyslexic too. And he's got a Ph.D. in mathematics. Because it's more of that like space stuff [gestures out from the top of her head]. Abstract mathematics. So you know it's like we have some special gifts and one of the things I've found in the world is to find a place where I can show who I am. And one of the ways I do that is by doing clay and showing it to people. And not everybody understands me, but then I don't understand everybody either.

Jane's disclosure of herself as a sculptor with dyslexia and a daughter of a father with dyslexia invites others to tell their learning stories as she tells her own. The apprentices respond to her invitation by excitedly adding their personal folk knowledge to the evolving community narrative of dyslexia. But Jane does not conclude her story here, instead she adds her knowledge of the specific spatial gifts associated with dyslexia, and authenticates this knowledge by providing her father as an example of an adult with dyslexia who has negotiated a successful, professional life. She describes her father's gifts in mathematics and abstract reasoning and, by implication, testifies to her own gifts in spatial thinking. This is likely to have been experienced as an important teaching/learning moment by the apprentices in that Jane engaged in the powerful process of not only recognizing or naming the conventional phenomenon of "dyslexia" but also going beyond recognition toward transformation. In casting "dyslexia" in 
a new way, Jane changes the word's connotation from "disability to ability" and the perceptual "ground" from "failure to succeed in the world" to "ability to succeed with proper subjective positioning in the world" (Merleau-Ponty, 1989). She is authorized to speak in this way because of her intimate knowledge of the "how" and "that" of the art of sculpture and dyslexia in action that affords her a "perspicacious way" of using language and seeing (Genova, 1995; Wittgenstein, 1958).

\section{May 1, 1998: Video and Video Transcript}

Lesley, Ellice, and Louise have returned to the studio with their busts. The students have been working on their busts for several sessions and are ready to add features like the lips and hair. Lesley and Louise finally settle into working at a table together while Ellice works alone. None of the other apprentices nor Jane have yet arrived. Ellice is using one of her tools to subtract some of the clay from the neck of her bust. As she works, she says:

Ellice: I like doing this, its fun. [After saying this, she looks up from her work, glances around the room]. . . . We're already starting and she's (Jane) not even here!

[Lesley and Louise look up somewhat startled. Shortly after, other apprentices and Jane begin to file in.]

Louise: We started working on our thing ...

Jane: $\quad$ That's right, no reason to wait for us ... Who is ready to begin sculpting the mouth?

[Several apprentices raise their hands, but most continue working on their busts, fully absorbed.]

Ms. Lawton: ... Watch anyways and then when she comes around you can ask her...

Jane: Okay [at the easel] here's our head [drawing sketch of a head]. What's at the halfway mark? Who remembers? [Several apprentices shout out "nose."] . . . I was going to teach you guys like those forms, you know nose, eyes, cheeks, mouth. You know, like what we've been doing first. And then we did the neck, then we did the skull. You know step by step. Then once you know how to do it you can then give personality to it. You know give it long hair. Make it a man or a woman. Old person. Some of you have already started that... Oh and the other thing to think about. If you guys can help each other like if somebody needs help.

Louise: Yeah. I needed help with the eye and she helped me [pointing to Lesley].

Jane: $\quad$ Yeah, that's really good. You know that's how artists do each other. They help each other out and share what they know. 
Jane's teaching/learning narrative is striking in the way apprentices are encouraged to engage with her, her assistants, and the other apprentices in dialogues about doing and thinking about sculpture. Learning here is located in the sharing of the craft and artistry of sculpture with Jane viewing this learning as distributed among all working artists, no matter what their level of expertise. In using this approach, she has created a learning setting in which apprentices are encouraged to seek out others who can provide the contexts that support their proximal development in sculpture (Cole, 1985; Rogoff, 1990). Thus, speaking with others in her studio context is viewed not as peripheral to learning, but rather an integral part of developing their understandings about doing and being sculptors. In this sense, Jane's way of teaching and learning, consonant with a sociocultural orientation, places the "dynamic edge of development" (Hickman, 1985) in the interactions between people.

Jane:

Samantha:

Jane:

Several apprentices:

[drawing on paper on easel] And for the mouth what I would do is I make a line like with one of those knives. And I cut this, the space where the mouth goes right here [makes an arc going down the face where the mouth goes like a horseshoe]. Like on old people. They have wrinkles right here. Because we can't just make the mouth which would be like a slit. Right? [Drawing an imaginary slit on her own face.] We have to make the forms around the mouth.... A lot of people think the mouth and the pigment are the lips. But as a sculptor we're trying to look at forms and images, like trying to think of the lips with no color. And there are all these forms here. And the pigment's just a little section.

Do you mean pigment like indent?

Pigment meaning like red. Like a color. A hue ... And then to make the lip. This is really fine. You guys, I have to sit in front of it to do it so if you can't see please come up. [Sits down and begins sculpting.] Because you all this is kind of like magic. It's really cool. Okay what I do. All we have is a simple little cut across right? Can you see where I had those balls [balls of clay placed previously on the lips to "get mass"] right there. What I do is I lift out the lips. So, I don't know how to say it any more. I lift it up. So I cut it and I pull up. [Using tool.]

Jane:

$\mathrm{Oh}$ !

The neater I do this. What we're doing is we're catching a shadow. And if you stroke the clay like one way it looks like that. And if you stroke it another way, it looks like that. So, it's like woodwork.... If you were sanding this table you'd rub it this way but the clay has certain grains to it too. So you can use these grains to create it to look like different flesh ... [is demonstrating by using a tool on her bust] Okay first we'll do the top one which means everything from under the nose to the top of the upper lip, and that's getting those planes. We talked about this one time. It's just not flat like where your mustache would be. It's just not flat. [Pressing her hands on her own face demonstrating the plane.] So I 
take a knife and push it back ... Right. Right. [Holding tool on her own face in that spot.] This is the highest part. And then it goes back [gestures back along her face]. Two planes back.

\section{May 15, 1998: Audio Tape}

This was the first day that the apprentices would meet the model for the full human-form sculpture. After Jane introduces the model and the assistant mentor who had come to help out with the sculpture apprenticeship that day, she talks to the apprentices about their busts.

Jane: First I want to tell you that your sculptures are just fantastic, I mean they came out so good. Every single person in here really did a good job and we're going to take pictures of them today too ... I mean the sculptures are really strong. You guys really spent a long time getting those forms together. Remember we spent such a long time doing the skull and the neck and the shoulders. And I think it really paid off because when you put those faces on them and the expressions and everything they just look so solid and believable and they're gonna holdup and you guys should keep those sculptures for the rest of your life. I mean they're really treasurable.... And the other thing was that I was really proud too of the quality of the work. You know when you were kids and you started drawing? You start drawing maybe at the age of one or two. You have a crayon and you scribble and those are your first drawings. Then as the years progress you draw more and more and pretty soon they get realistic and you do cartooning and you do better. But for some of you in this class, this is your first sculpture, so this is like your scribble when you were one. And when you think of that this is your beginning. This is your draft. This is the beginning of your life as a sculptor and stuff. You can see how fantastic they are. Because they hold up as art separate from just the process of learning. They hold up. And that's true in everyone ... so that I was really proud of you guys for that, and I was really proud of you guys for the part when the sculptures, I think for most people, got really hard. Either you knew you wanted to make a shape and you couldn't do it or it was just a bad day and it didn't feel good working on the clay or you were distracted from whatever it was and you guys persevered. And sometimes the sculptures broke and got smashed and it was like taking a deep breath and fixing it. Or sometimes it was like having to compromise like you might have wanted to make it look a certain way but we had to structurally make it strong and you guys did that. And so, you were really flexible but really focused on your goals. And that whole process of like making decisions and making mistakes and all that, that's all part of art, and being an artist. And you guys accomplished that too. And that's just an internal thing, like an internal gift that you have inside yourself now. And so I was just really delighted ... One of the things too that I found out is that if we are trying to make something and the voices in our head say oh god that is so ugly, I did such a bad job, that really doesn't look right, I'm not getting it. Then those voices in our head are the voices we use when we make our art. ... If you can change the voices in your head to say we're having fun here, this is sculpture, we're just making things and I'm trying. This is fun. This ear worked out good. This one didn't but I like the hair. 
... I noticed that when people kind of lighten up with it, when you're kinder to yourself you will be kinder to your art and your art will respond. If you're dogging your art, you know like this is so ugly you won't be in a relationship there of calmness and love, and your creativity will be blocked. Did I explain that? It's kind of spiritual, but it's really true. And like I've noticed some of you like the days that you're calm the best rather than the days when the critical part always wants us to get an A and be perfect and be the best. That doesn't really compute in art which is a spiritual thing. You know, you do it today and who knows what happens tomorrow. It's a process you know? Does anybody wanna talk about anything before we start doing the figure?

\section{[Later]}

Kim: Oh no. I need help.

Jane: You're doing fine.

Kim: ... bothering me

Jane: The chair on him comes right about here see? Your back is higher than the chair's back see?

Kim: It's deformed . . . I need help. Something's wrong. I don't know what part but it doesn't look like a chair. Like I need cut some of this off.

Jane: Take a knife and cut it off smooth like all the way around like here.

Kim: Okay.

Jane: Use your muscles. Be strong. You can do it. You're doing fine. Come around the circle. You did it. See?

Kim: Still doesn't look like a chair.

Jane: Well, now, see you just need to take your hand. Why don't you get closer to it? Then go boom, boom, boom. Make it thinner. See how this one's thin and this one's thick?

Kim: Where?

Jane: Make it even. See that's like an inch here and an inch there? Do it again.

Kim: Very thin. Okay. There.

Jane: Okay now. How would you get rid of that? . . Can cut it. These things are great for cutting. Have you taken sculpture before?

Kim: No. Actually yeah. Yeah I have at my old school [humming] Eeee I'm having fun.

Jane: Yep me too. You should do art.

Jane's mentorship uses enculturation to support and scaffold the apprentices into the critical aspects of doing sculpture, and thinking and seeing like an artist. Using Gee's notion of discourses as "ways of being in the world" (1996, p. viii), which include distinct kinds of behaving, thinking, speaking, and so forth that define a person as belonging to a certain group, Jane's classroom approach moves the apprentices toward mastery of the discourse of sculpture through initiating them into the social practices of sculpture. She uses both Gee's methods of acquisition, including modeling and practice, as well as the more analytical and explanatory approach of conventional teaching. Thus, she employs two-dimensional drawing to explain critical aspects of sculpture such as the use of fractions to locate facial features appropriately on the bust. However, she also models the use of this knowledge by sculpting on her own demonstration 
bust. Other knowledge involved in sculpting such as the use of forms, planes, and images is also "taught" and then demonstrated on her own sculpture. Jane's teaching narratives are also replete with analogies, supporting the apprentices' learning of a meta-knowledge about the art of sculpture. For example, she describes how being apprentice sculptors is akin to acquiring drawing skills, and how clay and wood both have grains in them. This kind of complex analogic reasoning stretches the apprentices to think beyond the discourse of sculpture into the other arts, here drawing, and into other aspects of the lifeworld, such as working with wood (Gee, 1996). These kinds of contrasts and comparisons are likely to raise their conscious awareness of some of the distinct properties of sculpture as a discourse as well as those that are shared with other art and craft discourses.

The work of Lave and Wenger (1991) on communities of legitimate peripheral participation (LPP) is another useful interpretive lens to bring to Jane's teaching/learning narratives. The LPP emphasizes that learning occurs in direct relationship to the kinds of relationships that afford students increasing amounts of legitimate participation.

Relationships within the LPP are designed to engage apprentices in the intellectual and social experiences of a particular discourse. Thus, as students' values about participation in a particular practice develop, they increasingly want to become fuller practitioners. In so doing they learn more about the social practice and they develop new identities. It would appear that the rich intellectual and social context created by Jane's teaching/learning narratives created a hospitable environment for those who would choose to become full participants in art and sculpture. Even with this kind of teaching/learning context, however, there are signs that some of the sculptor apprentices, such as Ellice, Samantha, and Brittany, are not as interested as others in increasing their levels of participation in the art of sculpture. In as much as this project was designed to explore the affordances of interest-based apprenticeship learning for students with difficulties in aspects of conventional school learning, the role that the apprentices' diverse interests in sculpture will play in their learning in sculpture is still to be explored.

\section{Speaking the Language of Art: Inside the Sculpture Studio-II}

\section{May 21, 1998: Audiotape Transcript}

While the apprentices worked on their full-figure sculptures, Jane interviewed each apprentice individually using three questions that she and the first author of this article had designed together. The questions were formulated to capture the apprentices' emerging learning about sculpture and themselves, and were to be used as part of the display in the IBIS Festival. At this culminating festival, all the apprentices' busts were to 
be placed on long tables in the gymnasium, and next to them would be framed photographs of each apprentice with her or his bust and his or her responses to these questions positioned underneath the photographs. This text will present the apprentices' and Jane's responses to the following questions: What is the most surprising or interesting thing you learned about sculpture? What is the most surprising or interesting thing you learned about yourself? and What is new inside of you because of your sculpture? Lesley and Brittany were absent on the day of this interview.

Dennis's, Paul's, Claire's, Louise's, Ted's, Kim's, Ms. Lawton's, and Jane's responses to these questions will be presented first because of their expressed interests in art and sculpture. Ellice's and Samantha's responses will follow. Using the same order of persons, we will focus on the apprentices' responses to the first two questions and subsequently present their views of the last question.

Jane:

What was the most surprising or interesting thing you learned in sculpture and what is the most surprising or

Dennis: interesting thing you learned about yourself?

... That I was good at it. I didn't know that you put the newspaper inside the head and you pushed the eyes in. I didn't know that I knew so much.

Paul: ... That it doesn't dry out very fast. I notice my facial features more. I didn't know I looked exactly like this.

Claire:

Louise: ... How to make the eyes. That I can do things with clay. I feel confidence.

... That when I was working on it, it could be fun to learn. I was also surprised that even when I mess up I can take it apart and do it again, because in my regular classes I don't think I could do the questions again.

Ted:

... About putting the newspaper in the head and when I took it out how smelly it was. I was also surprised that I could do it pretty good!

Kim: ... That sculpture was kinda fun. I was also surprised that I used a lot of skills like seeing, seeing geometric shapes in people, keep trying and worked hard.

Ms. Lawton:

... That I could really fix the mistakes I made sometimes, and that I liked it better after I fixed it. That we did a lot of math, and that the human body is not symmetrical-that people's ears and eyes are different. That I can do this, that I'm happy with some of what I've done. And I am surprised at how much my mood influences it. Somedays I like it and some days I don't like the same sculpture. I have to wait for my mood to change.

Jane [her written response]: ... That sometimes the clay tells me what to make. That in doing sculpture I am connected to something greater and more powerful than myself. 
Ellice:

Samantha:

Jane:

David:

Paul:

Claire:

Louise:

Ted:

Kim:

Ms. Lawton:

Jane:

Ellice:

Samantha:
... How I look at shapes, how I look at things like the shapes of people's chins and eyes. I was also surprised that if I think I can do something I really can. If I have a positive attitude about it.

... That sculpture is very stressful — getting the right shapes down and the forms. It is hard in general, it takes a lot of skill. I was also surprised that I did it! I finished! I had the patience. I didn't give up.

What is new inside of you because of sculpture?

I know what I look like better. I am happier.

I am happier that I can work so well with the clay.

I can do it, I can make the art look real.

I feel confident that I can finally do something that looks good.

I have more confidence that I can do that kind of stuff. That I can do clay better than I thought. I feel proud that I made a good sculpture.

I learned to see different things. I see people differently. I feel stronger inside.

I now know that there isn't a right way to do art. I quit my art classes in junior high and high school because I couldn't control my grades. Now I can do it my way and it is the right way for me.

I am stronger, more confident, softer, kinder, and very, very happy.

I actually know how to sculpt clay better and I want to sculpt more. I want to keep making things.

I know that I can do things now that I couldn't do before. If I thought I didn't have the patience or the time to be able to do it, I found I could.

In this interpretation, we will use these interview texts as a window into the ways that the apprentices' legitimate participation in the narrative discourse of sculpture affected what they learned and their interpretations of that learning. We will, also, pursue further the role that the nature of the students' interests in art plays in the quality of their learning in the sculpture apprenticeship.

All the apprentices, except Samantha, emphasized the positive aspect of sculpture. The aspects of learning sculpture that they mentioned were both how to "do" certain things to clay-make the eyes, put newspaper in the head, fix mistakes, use mathematics—and "how to think about" doing sculpture-noticing facial features, seeing geometric shapes in people, and looking at the shapes of people's eyes and chins. Relative to this question, only, Samantha, who had not initially expressed a specific interest in art but rather an interest in the art of cooking, described the process of doing sculpture and getting the right shapes down as hard and stressful.

However, all the sculptor apprentices and Jane described only positive personal effects of being engaged in the sculpture apprenticeship in their responses to the second and third questions. These ranged from coming 
to know one's physical appearance better, experiencing the surprise and pleasure in being able to do human form sculpture, feeling an increased sense of self-confidence, pride, and strength, recognizing the positive outcomes of persistence and positive self-talk, and coming to a new understanding of the primary self-expressive function of art rather than meeting the criteria-based forms defined by others.

We will suggest that these positive effects of being engaged in a sculpture apprenticeship are the consequence of several teaching/learning features. First, there is inevitably a positive level of affect associated with participating in an apprenticeship that the students, teacher, and mentor have freely chosen (Corno, 1992; Deci \& Ryan, 1985; Malone \& Lepper, 1987; Oldfather, 1995). Second, in as much as their selection of subject matter, in this case sculpture, approximated their genuine interests in learning, increased levels of affect and activation and intrinsic motivation have been found (Alexander, Kulikowich, \& Jetton, 1994; Csikszentmihalyi, 1975, 1990; Gottfried, 1985, 1990; McPhail et al., 2000; Schiefele, 1991). Third, the favorable "educational" positioning that results from choice and interest permits these apprentices to locate themselves in the discourse of sculpture in ways that resonate with their personal subjectivities (Davies \& Harre, 1990). Jane, as their mentor, herself favorably positioned as a sculptor, brought her own positive social and intellectual subjectivities to the discourse of sculpting. In having created a supportive, authentic, and meaningful context of learning for her apprentice sculptors, she scaffolded their participation in the discourse of sculpting. As a consequence, these apprentices performed as sculptors in ways that made them believe they were sculptors (Smith, 1995). In other words, not only did this experience permit them to present their personal interest story through the choices they made during all the discovery activities but, also, because of the enculturation structure of the apprenticeship, over time. Jane's subjective histories relative to herself as a sculptor, an individual with dyslexia, and an excellent teacher were integral to the creation of a context in which the apprentices were able to perform sculpture as sculptors.

Sculpture as a medium of art, also, would seem to be playing a significant role in the positive learning of the apprentices. First, the experience of art brings the artist into an intimate relationship with his or her past, present, and future through the instantiation of these subjectivities into the work of art (Dewey, 1934; Jackson, 1998). Thus, the artist sees himself or herself completed in some way in the work of art. Sarason (1988) would underscore the sense of accomplishment and satisfaction that comes when an artist makes something that in the making finds and remakes the artist. In Jackson's words, this kind of intimate transaction has the power to be "genuinely transformative, to modify irrevocably one's habitual ways of thinking, feeling and perceiving" (1998, p. xiv). Evidence from the apprentices in these interviews suggests that this apprenticeship may have afforded all of them some of these changes. 
We recognize that the apprentices' responses to these questions may have been influenced by the fact that the interviewer was their mentor, so we turn now to the apprentices' retrospective interviews conducted by the first and second author, who had not been able to get to know these students and their work well because their research responsibilities took them to two other interest-based apprenticeships in the school.

\section{Speaking the Language of Art: A Retrospective Look}

On June 1, approximately one week after the IBIS Festival, we interviewed the sculptor apprentices individually, and audio taped all the interviews. The second author, Joanne, interviewed Lesley and Kim, and the first author, Jean, interviewed everyone else, including Jane. Jane was interviewed, however, on August 1 in her sculpture studio and classroom. Everyone seemed pleased to talk about their experiences in sculpture, so we have elaborated responses.

For this text, however, we will focus only on the questions that address the apprentices' and mentor's learning about sculpture, learning of others through the sculpture apprenticeship, and their evaluations of their experiences in the sculpture apprenticeship. In terms of learning about sculpture, the following questions from the interview will serve as the foci: What do you now know about sculpture? What are some ways to solve the problem of creating a clay sculpture of a person? What advice do you have for anyone wanting to be a sculptor? In coming to understand the learning of others that resulted from their work in this apprenticeship, we will highlight the apprentices' and teacher's responses to the following question: Through working with the other students in your sculpture apprenticeship, did you see them in the same way or in a different way than you see them during the rest of the school day? Finally, to illuminate their evaluations of interest-based apprenticeship learning, we will use the apprentices' and mentor's responses to the question: What advice do you have for the university and teacher team about doing these interest groups again?

\footnotetext{
Interview Audiotape

Jean or Joanne: What do you now know about sculpture? What are some ways to solve the problem of creating a clay sculpture of a person? What advice do you have for anyone wanting to be a sculptor?

Dennis: [I learned that] you have to dig the sculpture out and then have it sit for three weeks. You use lots of newspaper in the clay. You take a lot of clay and square it for the model. You make the line when you're going to cut it out. You start digging it out and then you put the person in the piece of clay.... [I would advise anyone who wanted to be a sculptor] that it's hard.
} 
Paul:

Claire:

Lesley:

Ted:

Louise:

Kim:

Ms. Lawton:
[I learned that] you can put so much detail into clay, and that the body is made up of different shapes. I took a square piece of clay, cut the person out of it, and molded it. It takes time. If a body part breaks, you can fix it by taking clay and smoothing it back on. [I would advise anyone who wanted to be a sculptor] that you have to have patience and a lot of time. That you need to work around other people so that you can look at their facial expressions.

[I learned that] some of sculpting can be very hard. You need to get a model so then you would know what it looked like. You make a lot of changes because sometimes it doesn't look great. [I would advise anyone who wanted to be a sculptor] that it is very hard work, that it is hard to make it look how you wanted it to.

[I learned that] all that we did and the busts. I didn't know what they were called. I didn't know about the model. You have to use a lot of tools and clay. Loop tool, knife and there was another little, tiny loop tool. I forgot what they were called. You should follow step by step. Use your imagination. Like make stuff that is in your mind. [I would advise anyone who wanted to be a sculptor, that] if you really have a skill of doing it, really interested in it, you could do it. The tools- what you need. Have to learn what shapes you have to use. One of the busts uses a rectangle for the shoulder and a circle for the head, head kinda like an egg-shape. [I learned that] it is easier than I thought. I create a clay sculpture of a person by looking at a model, and looking at all of the little tiny features, every little detail, like freckles. You have to have someone who knows how to do it to help you. Sculpture takes a lot of time to do. [I would advise anyone who wanted to be a sculptor] to be patient. Your sculpture may not look good in the beginning, but it will look great in the end. Also, I would tell them to ask a lot of questions about how to do things.

[I learned that] if you mess up, you can take it off and do it again. You shouldn't try that hard at creating a clay sculpture because you can fix it if you don't like it. [I would advise anyone who wanted to be a sculptor] to keep saying to yourself, you're good at drawing, painting, have confidence in yourself.

[I learned] to make stuff, like the head and the eyes, that I couldn't do before. I made a clay person by fixing it, by taking the clay off and rebuilding it. [I would advise anyone who wanted to be a sculptor] that it is fun, but you have to work hard. You should not be aggravated with your work, because you can take it apart. Also it is important not to make fun of other people's project. I learned everything. I knew nothing about sculpture. Didn't know that there was lots of physiology in sculpture. I am thinking I could incorporate sculpture into science teaching. I didn't know how forgiving clay really is, and how nice it is to fix mistakes. I didn't know there was a lot of math. We were taught two different ways to build a sculpture - the blank board approach in which you build up from shapes, and the cake method in which you sculpted down to the person. I learned that a lot of kids relied on their tools. Some of the other kids and I relied on our hands. I learned to deal with frustration by leaving a problem and coming back to it. I also learned that my mood influences 
Ellice:

Brittany:

Samantha: my opinion of my work, and how I worked on it. I was impressed with the quality of work that was accomplished in sculpture, with so many nonschool things going on like music and conversation. I am now thinking about including music in my classes. That a lot of sculpture is training. I have a different respect for training now. I know because eight out of the ten kids did remarkably well. Also, that it is never too late to learn sculpture; Jane took it up at 26 or 27 , that is exactly my age now.

[I learned that] you have to add the basic forms of the shoulders, neck and head because they are all just shapes, and then you add details. [I would advise anyone who wanted to be a sculptor] to take a sculpting class.

[I learned that] sculpting is a lot of work, and that you have to put a lot of detail in sculptures. People have to go to school for sculpture. I learned that some days are good days for sculpting while others are bad days. To create a clay sculpture of a person, you have to think of it in shapes, go through steps such as putting the eyes in, the mouth, ears and hair and hollow it out when you're done. [I would advise anyone who wanted to be a sculptor] to give yourself time to do your work, do your best and know that you have good days and bad days.

[I learned that] sculpture involves a lot of work. I now have much more respect for artists because sculpture is much harder than it looks. To create a clay sculpture of a person, you should have an open and clear mind, be relaxed, get comfortable with the clay, have a picture of what you want to make, draw it out and have a model. [I would advise anyone who wanted to be a sculptor] that they should be very clear about what they're getting into because three-dimensional work is a big, big responsibility.

In coming to understand the learning of others that resulted from their work in this apprenticeship, we will highlight the apprentices' and teacher's responses to the following question.

Jean or Joanne: Through working with the other students in your sculpture apprenticeship, did you see them in the same way or in a different way than you see them during the rest of the school day?

Dennis: $\quad$ They were working real hard. Ted doesn't talk as much in sculpture as he does in science. Ms. Lawton was really paying attention to her sculpture, she usually doesn't look that carefully at the papers she is grading. Her sculpture was really good.

Paul: [I saw the students] differently, because normally I look at them and they're the same everyday, but after sculpture I started looking at their expressions and everything, and how their arms are really long and how their shoulders take up a lot of space.

Claire: [I saw the students] differently, because usually they're not really having fun and in sculpture they were.

Lesley: [I saw the students] differently, because in sculpture we get to do things on our own at our own speed. When we do subjects we have to work on a speed.

Ted: [I saw the students] differently, because they were more funny, friendly, more active and more talkative, sometimes Dennis talked too much. 
Louise:

Kim:

Ms. Lawton:

Ellice:

Brittany:

Samantha:
[I saw the students] different than in our other classes because the rest of our work isn't really hard. We're in the same books. This was really harder, you need to take time. The rest is easy, you can zip right through it.

[I saw the students] different. I never see them sculpt in other classes.

[I saw the students] definitely differently. I saw them as more relaxed, more social. Their conversations were more open. I watched kids learn to handle anxiety. Initially we [Jane and I] had to direct them, but later they directed themselves and others. I was impressed by how supportive they were with each other, they circulated around the room and complimented each other. I don't think I ever heard a negative comment. They all felt good about the work they were doing even though they were aware of frustration sometimes. They learned respect for other's work from watching Jane. She treats everyone and their work with respect. I saw how important teaching by example is.

I saw the other students differently because they seemed more relaxed and talked more.

[I saw the other students] the same and different ways than in my other classes. Samantha was the same, but Paul, Ted and Claire were different. Paul was very focused and getting things done in sculpture.

Ms. Lawton was different in sculpture than during the rest of the school day. We saw her stress side. Students don't usually see teachers stressed, don't see them try and learn something new.

Finally, we will use the apprentices', teacher's, and mentor's responses to the last question of the interview to illuminate their evaluations of interest-based apprenticeship learning.

Jean or Joanne: What advice do you have for the university team and teacher team about doing these interest groups again?

Dennis: It would be fun, kids would like it.

Paul: $\quad$ You guys are doing so good, I don't know. Maybe if a kid kinda didn't like the group they had selected they could change once. But, all, or most of the kids in art, really liked it. It was good that we weren't really rushed.

Claire: I liked it that we got to do fun things every Thursday and Friday instead of just being in the classroom.

Lesley: They're fun and you can learn things from it, things you might not have known.

Ted: You should do them for two and one half days instead of two days. I'd keep almost everything, except the binders [in which the apprentices recorded their in-situ responses to their experiences in the IBIS apprenticeships and their everyday classes].

Louise: I'd take time from gym. I think it gave the students a lot of thought about what they should do with their lives.

Kim: I don't have any [advice]. It all worked well. It just wasn't fun for me, because I don't like clay.

Ms. Lawton: I think these apprenticeship groups should take up less academic time or include more literacy. It needed one of two options, especially because we're talking about these kids-that they're so 
behind in their reading anyway, it either needs to be supplemental to the curriculum-add time onto the school day or otherwise we need to find ways to get more reading and writing into the groups. It was hard for all of us teachers to realize how much time we were losing in language arts ... depends on the group, obviously. Carly's group took time at the end to write, reflect, but that didn't happen in all the groups. There were some things that started to happen when you guys brought in the books. We could bring in books about sculptors, that might be a way to put in a reading component to an art class ... Also, the social issues, except in my group where there weren't any, need to be looked at. We had a nice, calm group, but by putting together kids just based on their interests, the mixture was difficult, so many of our interests relate to our personalities, needs to be looked at, look at the kids' personalities in the group, and say, maybe we'll need two mentors in this group, crowd control [laughs]. We just knew, because we knew the kids, we knew the mix. We just looked at some of these groups, and thought wow, that's gonna be a challenge [laughs].

Ellice: $\quad$ You should get more teachers so everyone would get their first choice.

Brittany: $\quad$ I think all of your ideas were very good, how you planned it. I just have a little suggestion. The one [the original description of Ah the Feel of It, the Taste of It, the Look of It on the student's list of choices] about the sculpture ... I think that that should, it kind of sounded more like cooking than sculpturing. So maybe change that paragraph a little bit. But everything else was very good. You did a very good job. Everything was planned very good.

Samantha: I think it's completely worth it, because I know a lot of kids in my class got to be with other people that they have the same interest in, people they might usually not hang out with. And I also think the teachers had a lot of fun. And everybody kind of learned, something about themselves through it.

The apprentices described learning about sculpture, each other, and curriculum possibilities in multiple ways and along multiple dimensions. Before addressing the learning themes that arose in these narratives, we will position our interpretation within the theoretical frames we have drawn on in this article. First, we view the learning and development described by these apprentices as being inextricably tied to the context of their learning (Wertsch, 1998; Vygotsky, 1987). Thus, the students' utterances are always considered from the educational positioning afforded by this project-as "learners-in-interaction-with-their-selected-interest-basedapprenticeship-setting." In this frame, then, the apprentices mediate their learning and development through the cultural tools afforded to them in this apprenticeship. In our interpretation, we will focus on the apprentices' interest-based motivation in interaction with the physical materials involved in doing sculpture, and the learning and interpersonal resources afforded to them by the sculpture apprenticeship. Second, we will use Wittgenstein's (1958) notion of complex learning to assess whether the 
apprentices learned both the "how" and "that" of learning in this apprenticeship experience. Third, we will draw on the writings of scholars who have explored the unique affordances of art-centered learning (Dewey, 1934; Eisner, 1982; Jackson, 1998; Sarason, 1988).

The specific learning that the apprentices mentioned relative to doing sculpture included understanding the critical material and process elements involved in creating a sculpture. Thus, they came to understand how shapes, physiology, mathematics, sculpting tools, and models, as well as one's imagination, are "material tools" critical to the creation of sculptures. They also acquired understandings relative to the artistic process. Apprentices described the importance of time, positive self-talk, the assistance of more expert others as well as others interested in art and sculpture, the power involved in viewing the fluidity or changing dynamics of an artistic creation, and the critical importance of "study" in learning art. Time to "do" sculpture, a recurrent theme in the talk of the apprentices, was often contrasted to the limited time they had to "do" their projects and assignments in their regular classes. The precious commodity of time seemed to give apprentices the freedom to persevere in the "trial and error" learning of sculpting, allowing them time to rework their sculpture over and over again until it met with their personal satisfaction. Through this process, they learned that there is no one "correct" answer. Jackson (1998), in explicating Dewey' views on art in Art in Experience, suggests that time has a different quality to it in an experience that is complete such as an art-centered experience. In art-centered experiences in which individuals bring "an experience to fruition" (Dewey, 1934, p. 6), for example, there is a sense of "consummation" not "cessation " (Jackson, 1998). The student apprentices' descriptions may suggest that they experienced the unusual pleasure, at least in school, of bringing a work to completion. And, in this case, this experience may have been intensified for them because of their expressed interests in doing art. Dewey (1913) describes the "unity" or "non-dualism" involved in interest as resulting from the "organic union" of the person, materials, and the results of his or her action. This kind of "unity" appears to be present in the narratives of all the apprentices except Ellice, Kate, Brittany, and Samantha; these apprentices decide, after their experiences in sculpture, that they do not experience sculpture as intrinsically rewarding. Yet, for the other apprentices, the experience of being engaged in a sculptor apprenticeship does contain Dewey's criterial aspects of an experience-sculpture has a cohesiveness to it for them and it tends to significantly engage them in intellectual and emotional ways.

The apprentices, on the whole, saw each other differently in the sculpture apprenticeship context than they saw each other during the rest of the day. One of the social affordances of this apprenticeship was the emphasis placed on learning between people as well as the objects involved in sculpture, a view consonant with socioconstructivist pedagogy (Dewey, 1913, 1916; Forman, Minick, \& Stone, 1993; Vygotsky, 1987, 1993; Wells, 
1995). Apprentices described differences they saw in each other in terms of affect, especially attention (Ms. Lawton was paying attention to her sculpture in a more intense way than she does to her papers), intense focus (Paul was very focused) and getting things done in sculpture, and openness (more relaxed, funny, friendly, talkative). Apprentices also described how affective challenges were met, especially the frustration and stress experienced while trying something new. The apprentices were surprised with themselves and with each other at how they learned to work through frustration and continue to persevere with their sculpting work. These understandings and realizations on the part of the apprentices (i.e., increased affect and activation, perseverance during challenges, and a deeper understanding of content) are consistent with the outcomes of interest-based learning (Dewey, 1913; Hidi, 1990; McPhail et al., 2000; Rathunde \& Czikszentmihalyi, 1993; Renninger, Hidi, \& Krapp, 1992; Schiefele, 1991; Tobias, 1994).

\section{One Story in Another}

The narratives of Brittany and Samantha, of Ms. Lawton, Ted, Kim, Louise, and Ellice, of Dennis, Paul, Claire, and Lesley constitute a socially constructed context nested in the larger story of the interest-based instructional curriculum of the IBIS apprenticeship. These apprenticeships were designed to create a curriculum that would enhance the intellectual and social development of students who are more vulnerable to the negative impact of a standard school curriculum on their learning.

The larger story, the curricular context that was created, was particularly important for the students in this study. The more typical context for students with learning disabilities is one in which what they see reflected back from their conventional curriculum is often a reflection of a "deficient" self, a self that has not yet met the challenges of the curriculum with success. Conversely, in the IBIS apprenticeships where the students had, in fact, successfully met the challenges of a rigorous curriculum, the apprentices' narratives of their experience reflected a positive understanding of self and peers. The apprentice sculptors saw reflections of their stories and their identities as successful agents within this larger context, a context that seemed to be effective due to four contextual threads, which were woven throughout the tale. These threads were: the apprentices' genuine interest in art, enculturation learning, the dialogic context established by Jane within the apprenticeship, and the role of art-centered experience in learning. Through their shared experiences with sculpture and each other, they wove a narrative of learning about the art of sculpture, each other, and themselves that included both the communal, meaning-making "voice" as well as the individual ways apprentices drew their singular meanings from their own positionings. 
In effect, through this experience, the apprentices were repositioned within the larger narrative of the curricular context. What the repositionings within the discursive practices of the apprenticeships afforded was the creation of multiple subjectivities for students who, by sixth grade, may have come to see themselves as unitary, as uniformly not up to the challenge of a conventional curriculum. The multiple positionings within the discursive practice of the IBIS apprenticeships allowed the students to see themselves and each other in a nonunitary way, in ways that have recently been illuminated by new theories of mind (Bruner, 1990, 1996; Davies \& Harre, 1990; Henriques et al., 1984; Lakoff \& Johnson, 1999; Smith, 1995) where mind is not unitary, but where mind is constituted by the subjectivized person. Additionally, this new positioning, essentially a new narrative presentation, had its effects not only on the understandings of the apprentices and Ms. Lawton, but also on significant others in their school environment. Among these individuals is one who is in the position to reflect on the larger context of the IBIS apprenticeship curriculum reform. We turn now to her responses to this project.

The final narrator from the school will be Carol, the lower-school director, who opened the doors of the school to an experience that was entirely new to them-a collaborative research study with a university. Carol's interests in the students and their experience of being at this school, the curriculum, and her own personal artistic interests came through very clearly throughout the year. Carol was an involved, supportive school administrator throughout the project, and kept a keen, researcher's eye on the effects of the project on the teachers, students, and parents of the school. She reflects on her own and other peripheral participants' (e.g., parents, other school personnel, etc.) experiences of the IBIS apprenticeships. When asked to reflect on the project as a whole, Carol told Joanne in her retrospective interview that:

Jane was the best [mentor], you know because she's probably the most seasonedshe's a teacher. What she was doing lent itself quite nicely to the project, because really what she was doing was having a studio class with them twice a week ... Ms. Lawton hadn't sculpted before, and she looked more engrossed than the kids did, and she communicates that joy to students, and that's a very powerful thing, I think, to be a teacher-as-learner, you know, kind of person.

Joanne: Did you see changes in the teachers?

Carol: Oh, yeah....just watching kids face frustration, getting past it, or bogging down in it, the risk-taking, the interpersonal things going on, they saw the kids in a different way.

Joanne: Did you see changes in the kids here?

Carol: Oh, yes-well, working past frustration, I don't call that self-confidence, that's pushing yourself, it's motivational, being able to defer gratification, break things down into steps, those are really hard things for the kids here to do. And they talked through things a lot as they were trying to solve problems. That's what I observed, was kids talking through things and working together, and that's, you know cooperative learning, group 
work. As we all know we have to do that as adults everyday, and these, this particular group of kids, I can tell you at our last two sixth grade council meetings were working better together than most adults, and I didn't see that before. And, I know the play [sixth grade production of West Side Story], helped them a lot too but I think this experience was very powerful, too. It's hard to isolate them, but I have a feeling that a lot more of it came from this experience, because they had to problem solve a lot. There's a confidence and self-assurance in these kids I haven't seen in a group at this school before. And it's not that their learning disabilities are less substantial.

Joanne: What are your thoughts on how this worked for kids with learning disabilities?

Carol: I saw growth in them. I wasn't surprised. These kids have a lot of creativity - and the more we tap into their creativity, the happier they're going to be. The more we encourage them to discover their interests, or a passion, identify a passion, the happier they're going to be, too. They have to see that they can have success in areas other than the traditional academic.... You see, there's always a rub here, the parents will, one of their criticisms, of our program is that we don't have enough art and music and drama, because they know these are things their kids are good at, but then the other end of it is, is somehow we're supposed to magically transform them into people without learning problems. So, that's always a problem. So, when there's a program like this the parents are just delighted, to see their kids get a lot of challenges. Like I said, they all wanted to know what was going to happen next year..."

\section{EPILOGUE}

In thinking about the provocative and challenging question of "What is going to happen next year?" we are challenged to come back to ourselves and "criss-cross the narrative" (Diamond, 2000, p. 9) tapestry with our own intellectual and emotional experiences in this project. What was the most surprising or interesting thing we learned about sculpture and ourselves? What is new inside of us because of sculpture? Did we see the students in the sculpture apprenticeship in the same way or in a different way than we saw them during the rest of the school day?

Being engaged in this work significantly shifted our ways of thinking about students identified with specific learning disabilities. First, we were surprised at the ways all the students enthusiastically embraced and struggled in the forms of literacy associated with the artistry of sculpture. Second, we were interested in the artistic quality of their sculptures. ${ }^{3}$ All the students persisted in engaging in the processes of learning and creating related to sculpture over the eight weeks, and as they persisted, they and their sculptures changed. They became interested, engaged, and competent learners in the sculpture apprenticeship, appearing no different than other focused learners not classified with "learning problems," and their sculptures developed in artistically interesting ways over time. As an interested visitor at the IBIS Festival confusedly said while observing 
these students and their busts, "I thought you said these kids had learning disabilities."

However, while we appreciated the students' developing abilities in the area of sculpture as a legitimate, representational form of literacy (Eisner, 1982), we are also challenged by Ms. Lawton's and Carol's responses to this work to think about ways to implement conventional forms of literacy into interest-based inquiry apprenticeships. We began to think about the numerous possibilities for fusing conventional literacies into the sculpture apprenticeship, such as the integration of trade magazines and sculptors' autobiographies and biographies, and the initiation of Web-based conversations/graphics with other sculptor apprentices and practicing sculptures.

In reflecting on what we find new inside of us because of this work we are led to Vygotsky (1993) in that while we wanted to believe him on the critical role of learning contexts relative to the kinds of quality of learning constructed, we hadn't clearly experienced this until this project. We came to appreciate the ways that Jane's expert guided learning ${ }^{4}$ in the sculpture apprenticeship appeared to provide the context for a new mediational means to develop for the students that engendered in them different kinds of actions (Wertsch, 1998). Davydov's (1995) writings also prompted us to think about how these students' personalities could have been developed and, perhaps, transformed through guided instruction that was designed from the "developmental and individual particularities" of the students and oriented toward the cultivation of their potentials in meaningful learning.

Through the work of this project, we can no longer "see" the learning trajectories of students with difficulties in acquiring and using conventional school literacies as "different" in kind from learners without those difficulties. ${ }^{5}$ Rather, we now view their potentialities to experience transformational learning as being enhanced or limited by educators' capabilities to create contexts that are educative for them. Having ourselves intellectually and emotionally experienced the power of this kind of teaching/ learning context, we are now further committed to continuing partnership work with mentors and students in which shared interest underlies the design of learning communities and, in turn, creates the space for authentic dialogue that enhances development and self-understanding for all learners.

\section{ACKNOWLEDGMENTS}

We would like to thank the directors, teachers, and students for their active support and participation in this project; you provided us an unexpectedly rich learning experience.

The first three authors were members of the university research team and active participants in all phases of the project. The fourth author was the sculptor mentor who not only guided the apprentices in the artistry of 
sculpture but, also, provided invaluable knowledge and insights to the university research team.

\section{NOTES}

1. Kim and Lesley, two students identified as having language impairment, wore wireless microphones as part of the second author's dissertation study.

2. All the sculptor apprentices' names are pseudonyms.

3. One student was identified by Jane as an emerging sculptor. Although that student's reading level was at the primer level, her bust displayed a complexity and perspective that, according to Jane, marked her as a gifted sculptor. Jane said that she only wished she had the money to grant her a scholarship to study sculpture in the best fine arts school in the world.

4. We have included substantial dialogic exchanges between Jane and her apprentices to highlight their evolving partnership, and to illustrate the ways Jane's teaching/learning narratives appeared to be appropriated by the students.

5. While composing this paper with her coauthors, the first author was compelled to enroll in an adult sculpture studio class with Jane because of her lack of understandings about the processes the students were involved in relative to learning the art and practice of sculpture.

\section{REFERENGES}

Alexander, P. A., J. M. Kulikowich, and T. L. Jetton. 1994. The role of subject-matter knowledge and interest in the processing of linear and nonlinear texts. Review of Educational Research 64 (2): 201-52.

Bruner, J. S. 1990. Acts of meaning. Cambridge, MA: Harvard University Press. . (1996). The culture of education. Cambridge, MA: Harvard University Press.

Clandinin, D. J., and M. F. Connelly. 1994. Personal experience methods. In Handbook of qualitative research, N. K. Densin and Y. S. Lincoln, eds., pp. 413-428. Thousand Oaks, CA: Sage Publications.

Cole, M. 1985. The zone of proximal development: Where culture and cognition create each other. In Culture, communication and cognition, J. V. Wertsch, ed. Cambridge, UK: Cambridge University Press.

Corno, L. 1992. Encouraging students to take responsibility for learning and performance. Elementary School Journal 93 (1): 69-83.

Csikszentmihalyi, M. 1975. Beyond boredom and anxiety. San Francisco: Jossey-Bass.

. 1990. Flow. New York: Harper Perennial.

Csikszentmihalyi, M., and R. Larson. 1984. Being adolescent. New York: Basic Books.

Davies, B., and R. Harre. 1990. Positioning: The discursive production of selves. Journal for the Theory of Social Behavior 20 (1): 43-63.

Davydov, V. 1995. The Influence of L. S. Vygotsky on Education Theory, Research and Practice. Educational Researcher 24 (3): 12-21.

Deci, E. L., and R. M. Ryan. 1985. Intrinsic motivation and self-determination in human behavior. New York: Plenum. 
Dewey, J. 1913. Interest and effort in education. Cambridge: Riverside Press, Houghton Mifflin Co.

- 1916. Democracy and education: An introduction to the philosophy of education. New York: MacMillan.

- 1934. Art as experience. New York: Minton, Balch.

Diamond, C. T. 2000. Turning landscape into parkland: Difficulties in changing direction. Curriculum Inquiry 30 (1): 1-11.

Eisner, E. 1982. Cognition and curriculum: A basis for deciding what to teach. New York: Longman.

Fink, R. P. 1995. Successful dyslexics: A constructivist study of passionate interest reading. Journal of Adolescent $\mathcal{E}$ Adult Literacy 39 (4): 268-80.

. 1998. Literacy development in successful men and women with dyslexia. Annals of Dyslexia 48: 311-46.

Forman, E., N. Minick, and C. A. Stone. 1993. Contexts for learning. Oxford: Oxford University Press.

Gardner, H. 1983. Frames of mind: The theory of multiple intelligences. New York: HarperCollins.

- 1993. Multiple intelligences: Theory in practice. New York: Basic Books.

Gee, J. P. 1996. Social linguistics and literacies: Ideology in discourses, 2nd ed. London: Taylor \& Francis.

Genova, J. 1995. Wittgenstein: A way of seeing. New York: Routledge.

Gottfried, A. E. 1985. Academic intrinsic motivation in elementary and junior high school students. Journal of Educational Psychology 77 (6): 631-45.

-1990. Academic intrinsic motivation in young elementary school children. Journal of Educational Psychology 82: 525-38.

Hearne, D., and Stone, S. 1995. Multiple intelligences and underachievement: Lessons from individuals with learning disabilities. Journal of Learning Disabilities 28 (7): 439-448.

Henriques, J., W. Hollway, C. Urwin, C. Venn, and W. Walkerdine. 1984. Changing the subject: Psychology, social regulation, and subjectivity. New York: Methuen.

Hickman, M. 1985. The implications of discourse skills in Vygotsky's developmental theory. In Culture, communication and cognition, J. V. Wertsch, ed., pp. 236-257. Cambridge, UK: Cambridge University Press.

Hidi, S. 1990. Interest and its contribution as a mental resource for learning. Review of Educational Research 60 (4): 549-71.

Jackson, P. 1998. John Dewey and the lessons of art. New Haven, CT: Yale University Press.

Lakoff, G., and M. Johnson. 1999. Philosophy in the flesh: The embodied mind and its challenge to western thought. New York: Basic Books.

Lave, J., and E. Wenger. 1991. Situated learning: Legitimate peripheral participation. New York: Cambridge University Press.

Malone, T. W., and M. R. Lepper. 1987. Making learning fun: A taxonomy of intrinsic motivations for learning. In Aptitude, learning, and instruction, R. E Snow and M. J. Farr, eds., pp. 223-253. Hillsdale, NJ: Lawrence Erlbaum.

McPhail, J. C., J. M. Pierson, J. G. Freeman, J. Goodman, and A. Ayappa. 2000. The role of interest in fostering sixth grade students' identities as competent learners. Curriculum Inquiry 30 (1): 43-70.

Merleau-Ponty, J. (1989). Phenomenology of perception. New York: Humanities Press.

Oldfather, P. 1995. Commentary: What's needed to maintain and extend motivation for literacy in the middle grades. Journal of Reading 38 (6): 420-22.

Polkinghorne, D. 1988. Narrative knowing and the human sciences. Albany: State University of New York Press. 
Rathunde, K. 1993. The experience of interest: A theoretical and empirical look at its role in adolescent talent development. Advances in Motivation and Achievement: Motivation and Adolescent Development 8: 59-98.

Rathunde, K., and M. Csikszentmihalyi. 1993. Undivided interest and the growth of talent: A longitudinal study of adolescents. Journal of Youth and Adolescence 22 (4): 385-405.

Reiff, H. B., P. J. Gerber, and R. Ginsberg. 1997. Exceeding expectations: Successful adults with learning disabilities. Austin, TX: Pro-ed.

Renninger, K. A. 1987. Do individual interests make a difference? Essays by the Spencer Fellows IV, pp. 228-53. Cambridge, MA: National Academy of Education.

Renninger, K. A., S. Hidi, and A. Krapp. 1992. The role of interest in learning and development. Hillsdale, NJ: Hove \& London.

Rogoff, B. 1990. Apprenticeship in thinking: Cognitive development in social context. New York: Oxford University Press.

Sarason, S. 1988. The challenge of art to psychology. New Haven, CT: Yale University Press.

Schiefele, U. 1991. Interest, learning, and motivation. Educational Psychologist 26 (3 \& 4): 299-323.

Smith, S. 1995. Performativity, autobiographical practice, resistance. Autobiography Studies 10 (1): 17-34.

Sternberg, R. J. 1994. Mind in context: Interactionist perspectives on human intelligence. New York: Cambridge University Press.

Tobias, S. 1994. Interest, achievement and vocational choice. European Journal of Science Education 5: 299-307.

Vygotsky, L. S. 1987. Problems of general psychology, N. Minick, trans., vol. 1. New York: Plenum Press.

1993. Fundamentals of defectology, J. E. Knox and C. B. Stevens, trans., vol. 2. New York: Plenum Press.

Wells, G. 1995. Language and the inquiry-oriented curriculum. Curriculum Inquiry 25: 233-69.

Wertsch, J. 1998. Mind as action. Oxford: Oxford University Press.

West, T. G. 1991. In the mind's eye. Amherst, MA: Prometheus Books.

Wittgenstein, L. 1958. Philosophical investigations. New York: Macmillan. 